https://nv.nltu.edu.ua

https://doi.org/10.15421/40280726

ISSN 2519-2477 (online)

Article received $14.09 .2018 \mathrm{p}$.

Article accepted 26.09.2018 p.

$@ \bowtie$ Correspondence author

УДК 550.8.05

Р. М. Камінський' , Н. Б. Шаховська', Л. Г. Савків ${ }^{2}$, Я. Ю. Варецький', С. В. Саварин ${ }^{1}$

${ }^{1}$ Начіональний університет "Львівська політехніка", м. Львів, Україна

${ }^{2}$ Карпатське відділення Інституту геофізики ім. С. І. Субботіна, НАН Украӥни, м. Львів, Украӥна

\title{
МЕТОД ПОПЕРЕДНЬОГО ОБРОБЛЕННЯ ПЕРВИННИХ ГЕОЕЛЕКТРОМАГНІТНИХ ДАНИХ, ОТРИМАНИХ ІЗ РЕЖИМНОЇ ГЕОФІЗИЧНОЇ АВТОМАТИЧНОЇ СТАНЦІЇ
}

Подано результати попереднього оброблення первинних даних, отриманих із режимної геофізичної автоматичної станції. Як методи оброблення використано описову статистику та моделювання часових рядів. Подання результатів багатовимірними графіками дало змогу виявити феномен збігу в першому показнику описової статистики, а в другому - збіг коефіцієнтів моделі для подобових вимірів природного електричного поля. Використання мір центральної тенденції та мір варіації дають не лише основні загальні характеристики отриманої вибірки даних, але i їх подання у вигляді багатоелементного графіка, що дає змогу виявити окремі специфічні точки для послідовності діб місяця. Їхня специфічність полягає в тому, що вони вказують на доби, які за цими показниками $є$ найбільш подібні між собою. Цей феномен можна трактувати по-різному: відсутність зовнішніх впливів, у ці доби відбувся один і той самий вплив тощо. Цілком зрозуміло, що на всьому проміжку, отриманих за весь час роботи станції даних, цей феномен повинен мати якесь пояснення в майбутніх дослідженнях. Тому використання методів описової статистики та часових рядів $є$ доцільним для оброблення первинних даних, оскільки їх результати визначають нові задачі для подальшого аналізу не тільки геофізичних даних, але й інших подібних явищ, таких як: кардіологічні сигнали, показники сонячної активності та інші.

Ключові слова: дослідження постійного природного електричного поля; попереднє оброблення первинних геоелектромагнітних даних; метод природного електричного поля.

Вступ. Для дослідження та вивчення фізичних процесів і явищ, що відбуваються у поверхневих шарах та надрах Землі, а також на їі поверхні й в навколоземному просторі, використовують різноманітні геофізичні методи та методики. Такі дослідження організовують у різний спосіб: це можуть бути систематичні наукові дослідження у формі безперервного моніторингу чи режимних геофізичних спостережень, або ж періодичні вивчення окремих регіонів чи площ. Кожен із таких напрямів дає важливу первинну інформацію для подальшого вивчення цих процесів.

Безперервні геофізичні спостереження ведуть постійно в стаціонарних та тимчасових пунктах спостережень. На сьогодні, збір та реєстрація фізичних полів відбувається переважно автоматично, способом створення і поповнення різноманітних баз даних. За даними регулярних та багаторічних спостережень можна оцінювати та аналізувати параметри полів та їхні характе- ристики, вивчати динаміку змін протягом тривалого періоду, контролювати критично важливі показники. Зазвичай подібні дослідження забезпечують міжнародні мережі, світові та національні центри, консорціуми, геологічні, екологічні та інші служби, об'єднання, агентства. Ці організації, окрім інших типів даних, працюють 3 геомагнітними, сейсмічними, магнітотелуричними спостереженнями, формують відповідні архіви, подають візуальне представлення таких даних у режимі онлайн i, крім того, надають спеціальний або безпосередній доступ до них.

Однак, поряд із таким масштабним вивченням світового рівня геофізичної інформації, значний інтерес у царині геофізики мають і локальні дослідження окремих регіонів чи окремих ділянок земної поверхні. Такі локальні дослідження корисні тим, що дають змогу глибше, точніше і докладніше вивчати конкретний регіон, досліджувати локальні зміни чи особливості, харак-

\section{Інформація про авторів:}

Камінський Роман Миколайович, д-р техн. наук, професор, кафедра систем штучного інтелекту. Email: kaminsky.roman@gmail.com

Шаховська Наталія Богданівна, д-р техн. наук, професор, завідувач кафедри систем штучного інтелекту. Email: Natalya233@gmail.com; https://orcid.org/0000-0002-6875-8534

Савків лідія Григорівна, асистент, кафедра систем штучного інтелекту. Email: Natalya233@gmail.com

Варецький Ярема Юрійович, канд. техн. наук, асистент, кафедра систем штучного інтелекту.

Email: yarema.varetskyy@globallogic.com

Саварин Сергій Вікторович, асистент, кафедра систем штучного інтелекту. Email: vir.GOST@gmail.com

Цитування за ДСтУ: Камінський Р. М., Шаховська Н. Б., Савків Л. Г., Варецький Я. Ю., Саварин С. В. Метод попереднього оброблення первинних геоелектромагнітних даних, отриманих із режимної геофізичної автоматичної станції. Науковий вісник НЛТУ України. 2018, т. 28, № 7. С. 126-134.

Citation APA: Kaminsky, R. M., Shakhovska, N. B., Savkiv, L. G., Varetsky, Ya.Yu., \& Savaryn, S. V. (2018). The method of preview processing of the primary geoelectromagnetic data received from a modified geophysical automatic station. Scientific Bulletin of UNFU, 28(7), 126-134. https://doi.org/10.15421/40280726 
терні саме для цієї області. Окрім цього, такі відомості можуть бути важливою допоміжною, додатковою інформацією для оброблення та аналізу глобальних геофізичних даних.

Постановка проблеми та формулювання мети дослідження. Переважно автоматичні стаціонарні пункти спостережень геофізичних даних представляють собою структури, утворені набором спеціальних сенсорів (давачів), реєструючої апаратури та засобів передачі інформації в пункти призначення. Отримані дані відповідно кодуються і передаються в режимі, практично реального часу, у відповідні організації для оброблення та збереження. Особливістю таких даних є те, що їхній збір триває вже досить довго, причому вимірювання значень геофізичних параметрів здійснюються постійно і через короткі проміжки часу, наприклад, у цьому випадку, через кожні 5 хв., протягом години, доби, місяця, року і так з року в рік. Очевидно, що такі обсяги даних потребують спеціальних методів, математичного, програмного та комп'ютерного забезпечення.

Метою дослідження є орієнтація на вибір простих методів первинного оброблення даних та розробку відповідних математичних моделей динаміки їх розвитку в сенсі створення спеціального Websitey для відповідних служб та наукових дослідників.

Аналіз літературних джерел. Проведений аналіз літературних джерел свідчить, що багато сайтів та організацій світового рівня і глобального масштабу давно працюють, аналізують і представляють результати геофізичних спостережень в реальності: Міжнародна мережа геомагнітних обсерваторій INTERMAGNET (2018a, 2018b), Національні центри екологічної інформації (NCEI, м. Ашвілл, Північна Кароліна, США, 2018a, 2018b), Міжнародний консорціум сейсмологічних інститутів (IRIS, США, 2018a, 2018b), Геологічна служба США (United States Geological Survey USGS, 2018). Значну увагу приділено сейсмологічним даним як в Україні, так і за кордоном (Verbytskyi et al., 2009; Verbytskyi \& Verbytskyi, 2011; Verbytskyi, 2013; Haniiev, 2008; Haniiev et al., 2011; IRIS, 2018a, 2018b; ISC, 2018; EMSC, 2018). Проте локальні електромагнітні спостереження і питання оброблення такого типу даних регіонального характеру на сьогодні висвітлені вкрай мало. Цікавою з цього приводу є робота (Cletus C. Blum et al., 2017), де порушено питання $з$ організації геоелектричного моніторингу на магнітній обсерваторії Боулдер Геологічної служби США. Прикладом статистичного аналізу та оброблення даних мережі атмосферних вимірювань $є$ робота (David Fuertes et al., 2018). Подібним за характером подання подобових даних та їх оброблення $\epsilon$ дослідження (Mazurkin, 2016), яке стосується аналізу динаміки продажу нафти, в якому наведено показники середньої ціни, розмах значень ціни, обсяг продажу. Крім того, також проведено аналіз та моделювання тренду подобового часового ряду, візуалізацію закономірностей представлено графічно.

Виклад основного матеріалу дослідження. Характерні особливості постійних локальних електромагнітних досліджень можна розглянути на прикладі РГС "Нижнє Селище" (Закарпатська область, Хустський район, географічні координати: 48.197472 ${ }^{\circ}$ пн.ш., $23.456028^{\circ}$ сх.д.). Станція розташована на території Закарпатської сейсмоактивної зони, тому, окрім інших ге- офізичних вимірювань, на станції ведуться неперервні електромагнітні спостереження.

Для досліджень використовують метод природного електричного поля (ПЕП), суть якого полягає у визначенні параметрів ПЕП у двох взаємно перпендикулярних напрямках: північ-південь (Пн-Пд), захід-схід (ЗхCx). Для цього на території режимної геофізичної станції розгорнуто відповідну вимірювальну установку. Вона складається 3 двох пар електродів, що розташовані строго у напрямку Пн-Пд, Зх-Сх. Електроди кожної пари зафіксовані на певній віддалі, а саме: електроди напрямку Пн-Пд знаходяться на відстані 60 м один від одного, $3 \mathrm{x}-\mathrm{Cx}-80$ м.

Варто також зазначити, що установка є стаціонарна, забезпечує вимірювання ПЕП у двох напрямках, реєстрація інформаційних сигналів відбувається за єдиною методикою 3 використанням незмінного складу апаратури. Схему установки зображено на рис. 1, принцип роботи такий: дві пари електродів постійно вимірюють аналогові значення канальних напруг $\mathrm{K}_{1}, \mathrm{~K}_{2}$, що відповідають різниці потенціалів $\mathrm{E}_{1}, \mathrm{E}_{2}$ на електродах напрямку Пн-Пд $\left(\mathrm{E}_{1}\right), 3 \mathrm{x}-\mathrm{Cx}\left(\mathrm{E}_{2}\right)$. Надалі ці сигнали через аналогово-цифрові перетворювачі перетворюються у цифрові.

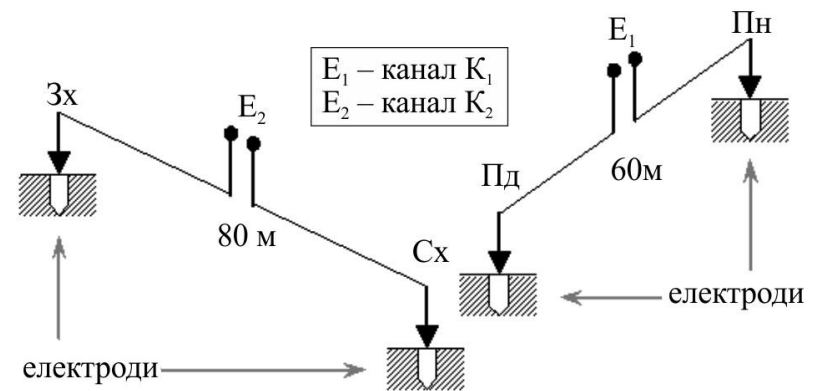

Рис. 1. Схема вимірювальної установки для постійних досліджень ПЕП на РГС "Нижнє Селище"

Отриманий файл даних містить таку інформацію: у комірці $\mathrm{A}_{2}$ зазначено дату проведення вимірів, тобто яка доба в комірці $\mathrm{B}_{2}$ - назва станції, в комірках $\mathrm{A}_{3}, \mathrm{~B}_{3} \mathrm{i}$ $\mathrm{C}_{3}$ - специфічна технічна інформація, у стовпчику $\mathrm{A}$, починаючи 3 комірки $\mathrm{A}_{4}$, подаються значення годин та хвилин із 5-хвилинним інтервалом. У стовпчику В, починаючи із комірки $\mathrm{B}_{4}$, вказується число місяця 19 липня і в наступних 12 клітинках, починаючи з $\mathrm{B}_{5}$, 3 інтервалом у 5 хвилин, подаються значення електричного поля 3 першого каналу $-\mathrm{K}_{1}$. У комірці $\mathrm{B}_{17}$ знову вказано число місяця 19 липня і далі, 12 значень електричного поля виміряних із 5-хвилинним інтервалом, і так до закінчення доби, причому останній відлік відповідає 23 годині 55 хвилин. У комірці $\mathrm{C}_{4}$ приводиться значення температури, яке варто читати як $23,68^{\circ} \mathrm{C}$, а починаючи 3 комірки $\mathrm{C}_{5}$, подаються значення електричного поля через кожні 5 хвилин 3 другого каналу $-\mathrm{K}_{2}$. У комірці $\mathrm{C}_{17}$ приводиться знову значення температури $\mathrm{i}$ наступні 12 клітинок - це значення електричного поля другого каналу.

Хоча така форма є зрозуміла для фахівців, проте вона $є$ досить незручною навіть для попереднього оброблення, оскільки потребує додаткового перетворення у стандартні формати. Іншими словами, потрібно виключити неінформативні показники години, дати і температури і створити для них відповідне подання, наприклад у формі окремих стовпців, певних міток тощо (рис. 2). 


\begin{tabular}{|c|c|c|c|c|c|c|c|c|c|c|}
\hline 4 & A & B & & C & D & $\mathrm{E}$ & $\mathrm{F}$ & G & $\mathrm{H}$ & 1 \\
\hline 1. & \multicolumn{10}{|c|}{ The original data from hardware } \\
\hline 2 & \multicolumn{4}{|c|}{19072017 NSEL } & \multicolumn{2}{|c|}{$45 \mathrm{k} 0716$} & -4470 & \multicolumn{2}{|c|}{$20 \mathrm{k} 0818$} & -4346 \\
\hline 3 & 6767 & & \multicolumn{2}{|c|}{$17-4.72$} & \multicolumn{2}{|c|}{$50 \mathrm{k} 0693$} & -4470 & \multicolumn{2}{|c|}{$25 \mathrm{k} 0756$} & -4430 \\
\hline 4 & \multirow{2}{*}{\multicolumn{3}{|c|}{$0: 00{ }^{\mathrm{k} 1017}{ }^{19}$}} & 2368 & \multicolumn{2}{|c|}{$55 \mathrm{k} 0739$} & -4457 & \multicolumn{2}{|c|}{$30 \mathrm{k} 0785$} & -4372 \\
\hline 5 & & & & -4105 & 12:00 & 19 & 2394 & \multicolumn{2}{|c|}{$35 \mathrm{k} 0782$} & -4278 \\
\hline 6 & \multicolumn{3}{|c|}{$5 \mathrm{k} 1051$} & -4124 & \multicolumn{2}{|c|}{$0 \mathrm{k} 0762$} & -4464 & \multicolumn{2}{|c|}{$40 \mathrm{k} 0685$} & -4370 \\
\hline 7 & \multicolumn{3}{|c|}{$10 \mathrm{k} 1082$} & -4087 & \multicolumn{2}{|c|}{$5 \mathrm{k} 0766$} & -4505 & \multicolumn{2}{|c|}{$45 \mathrm{k} 0748$} & -4393 \\
\hline 8 & \multicolumn{3}{|c|}{$15 \mathrm{k} 1115$} & -4081 & \multicolumn{2}{|c|}{$10 \mathrm{k} 0697$} & -4610 & \multirow{2}{*}{\multicolumn{2}{|c|}{$50 \mathrm{k0821}$}} & -4333 \\
\hline 9 & \multicolumn{3}{|c|}{$20 \mathrm{k} 1109$} & -4109 & \multicolumn{2}{|c|}{$15 \mathrm{k} 0722$} & -4436 & & & -4371 \\
\hline 10 & \multicolumn{3}{|c|}{$25 \mathrm{k} 1148$} & -4036 & \multicolumn{2}{|c|}{20 k0704 } & -4494 & \multicolumn{2}{|c|}{$55 \mathrm{k0844}$} & 2462 \\
\hline 11 & \multicolumn{3}{|c|}{$30 \mathrm{k} 1119$} & -4083 & \multicolumn{2}{|c|}{$25 \mathrm{k} 0571$} & -4459 & \multicolumn{2}{|c|}{$0 \mathrm{k} 0827$} & -3480 \\
\hline 12 & \multicolumn{3}{|c|}{$35 \mathrm{k} 1136$} & -4060 & \multicolumn{2}{|c|}{$30 \mathrm{k} 0657$} & -4483 & \multicolumn{2}{|c|}{$5 \mathrm{k} 0861$} & -4339 \\
\hline 13 & \multicolumn{3}{|c|}{$40 \mathrm{k} 1127$} & -4114 & & 5510 & -4454 & & 80830 & -4337 \\
\hline 14 & & 1126 & & -4084 & & 0581 & -4503 & & 00899 & -4300 \\
\hline 15 & & 1113 & & -4099 & & 0639 & -4448 & & 00812 & -4349 \\
\hline 16 & & 1179 & & -4036 & & 0535 & -4476 & & $<0884$ & -4329 \\
\hline 17 & 1:00 & & 19 & 2351 & & 5523 & -4526 & & $\mathrm{k} 0850$ & -4336 \\
\hline 18 & & 1209 & & -4023 & $13: 00$ & 19 & 2400 & & 0077 & -4301 \\
\hline 19 & & 1204 & & -4043 & & 0582 & -4530 & & $<0919$ & -430 \\
\hline 20 & & 1193 & & -4052 & & 5588 & -4545 & & $<0913$ & -4313 \\
\hline 21 & & 1154 & & -390 & & 5866 & -4508 & & $<0900$ & -4312 \\
\hline 22 & $\ldots$ & $\ldots$ & & $\ldots$ & $\ldots$ & $\ldots$ & $\ldots$ & & 00872 & -4322 \\
\hline
\end{tabular}

Рис. 2. Файл за 19.07.2017 р. з оригінальними (первинними) даними природного електричного поля, що надійшов на сервер із режимної геофізичної станції "Нижнє Селище"

Підготовка даних для інтерпретації. Отримані дані мають надзвичайно великий обсяг, що створює значні труднощі для їх оброблення. Лише протягом доби вибірка містить 288 варіант, що є достатньо для репрезентативного статистичного дослідження. Якщо розглядати дані за місяць (30 днів), то обсяг вибірки становитиме 8640 значень варіант, а за рік (365 днів)103680 значень. Очевидно, аналіз таких даних варто здійснювати, використовуючи більш короткі інтервали часу спостережень, і загальний висновок робити на підставі отриманих результатів, наприклад в межах доби, місяця. Тоді, зіставляючи подобові дані, отримуємо ситуацію протягом місяця, а зіставляючи щомісячні дані, отримуємо ситуацію протягом року тощо.

Другим моментом є те, що дані цих спостережень, фактично, є неперервно-дискретним випадковим процесом або, іншими словами, їх можна віднести до категорії нестаціонарних еквідистантних часових рядів. У цьому випадку, оброблення такого часового ряду потребує побудови математичної моделі, яка має характеризувати його загальну тенденцію та відповідні параметри його структури. Статистичну експрес-обробку отриманих електромагнітних даних пропонують розділити на кілька етапів.

Етап 1. Подання подобової динаміки показників описової статистики у вигляді загального графіка місячної тривалості.

Етап 2. Моделювання подобової динаміки розвитку процесу з обгрунтуванням вибору математичної моделі.
Етап 3. Визначення ролі динаміки коефіцієнтів моделі, апроксимуючої добовий тренд, способом виявлення збігів моделей у різних точках досліджуваного процесу.

Отже, внаслідок цілодобової роботи стаціонарного пункту постійних вимірювань електричного поля отримують набір, певним чином представлених даних електричної складової геофізичних показників, для відповідного місця локалізації.

Визначення показників описової статистики. Нехай отримані геофізичні дані, які представляють значення динаміки показників постійного електричного поля, тобто вибірка $X=\left\{x: x_{1}, x_{2}, \ldots, x_{n} \& \mathrm{n}=288\right\}$ характеризує його значення протягом доби. Найпоширенішими в цьому випадку методами попереднього оброблення даних $є$ методи визначення показників описової статистики. Ці показники описують і подають основні статистичні властивості даних. Вони дають змогу узагальнювати первинні результати і використовують їх для розв'язання таких двох задач: показати загальне в характері сукупності даних; показати в чому і наскільки дані різняться між собою. Для вирішення першої задачі ми використали показники центральної тенденції - середнє арифметичне, медіана, мода, а для вирішення другої - показники варіації, в яку включено середнє квадратичне відхилення, розмах (інтервал). Показник дисперсії не використовували, оскільки він є квадратом середньоквадратичного відхилення. Крім того, замість показника дисперсії, використано коефіцієнт варіації. Його функція у цьому дослідженні - це визначення мінливості досліджуваного показника - значення постійного електричного поля як відношення середньоквадратичного відхилення до середнього арифметичного.

Дані, отримані протягом однієї доби, наведено в табл. 1.

Враховуючи значний обсяг даних протягом однієї доби, на рис. 3 подано декілька добових графіків даних за порядком їх отримання у часі.

Практично форми тенденції зміни величини значень електричного поля є між собою дуже подібними, що свідчить про вплив невідомого на сьогодні чинника, який в межах доби впливає одним і цим самим чином на величину електричного поля. Специфічною особливістю його дії $є$ те, що можна досить чітко розмежувати його поведінку, поділивши добу на чотири приблизно однакові інтервали, тобто на 6-годинні інтервали. 3 графіка випливає, що в першому інтервалі значення електричного поля монотонно зростає.

Табл. 1. 5-хвилинні значення природного електричного поля за добу

\begin{tabular}{|c|c|c|c|c|c|c|c|c|}
\hline № 3/п & $\begin{array}{c}\text { години: } \\
\text { хвилини }\end{array}$ & $\begin{array}{c}\text { значення на } \\
19.07 .2017 \text { p. }\end{array}$ & № 3/п & $\begin{array}{c}\text { години: } \\
\text { хвилини }\end{array}$ & $\begin{array}{c}\text { 3начення на } \\
19.07 .2017\end{array}$. № 3/п & $\begin{array}{c}\text { години: } \\
\text { хвилини }\end{array}$ & $\begin{array}{c}\text { значення на } \\
19.07 .2017 \text { р. }\end{array}$ \\
\hline 1 & $0: 00$ & 110,17 & 21 & $1: 40$ & 112 & $\cdots$ & $\cdots$ & $\cdots$ \\
\hline 2 & $0: 05$ & 110,51 & 22 & $1: 45$ & 111,65 & 274 & $22: 45$ & 107,48 \\
\hline 3 & $0: 10$ & 110,82 & 23 & $1: 50$ & 112,42 & 275 & $22: 50$ & 108,21 \\
\hline 4 & $0: 15$ & 111,15 & 24 & $1: 55$ & 112,57 & 276 & $22: 55$ & 108,44 \\
\hline 5 & $0: 20$ & 111,09 & 25 & $2: 00$ & 112,22 & 277 & $23: 00$ & 108,27 \\
\hline 6 & $0: 25$ & 111,48 & 26 & $2: 05$ & 112,62 & 278 & $23: 05$ & 108,61 \\
\hline 7 & $0: 30$ & 111,19 & 27 & $2: 10$ & 112,78 & 279 & $23: 10$ & 108,3 \\
\hline 8 & $0: 35$ & 111,36 & 28 & $2: 15$ & 112,96 & 280 & $23: 15$ & 108,99 \\
\hline 9 & $0: 40$ & 111,27 & 29 & $2: 20$ & 112,56 & 281 & $23: 20$ & 108,12 \\
\hline 10 & $0: 45$ & 111,26 & 30 & $2: 25$ & 112,37 & 282 & $23: 25$ & 108,84 \\
\hline 11 & $0: 50$ & 111,13 & 31 & $2: 30$ & 112,84 & 283 & $23: 30$ & 108,5 \\
\hline 12 & $0: 55$ & 111,79 & 32 & $2: 35$ & 112,87 & 284 & $23: 35$ & 108,77 \\
\hline 13 & $1: 00$ & 112,09 & 33 & $2: 40$ & 112,84 & 285 & $23: 40$ & 109,19 \\
\hline 14 & $1: 05$ & 112,04 & 34 & $2: 45$ & 113,08 & 286 & $23: 45$ & 109,13 \\
\hline 15 & $1: 10$ & 111,93 & 35 & $2: 50$ & 113,16 & 287 & $23: 50$ & 109 \\
\hline$\cdots$ & $\cdots$ & $\cdots$ & $\cdots$ & $\cdots$ & $\cdots$ & 288 & $23: 55$ & 108,72 \\
\hline
\end{tabular}



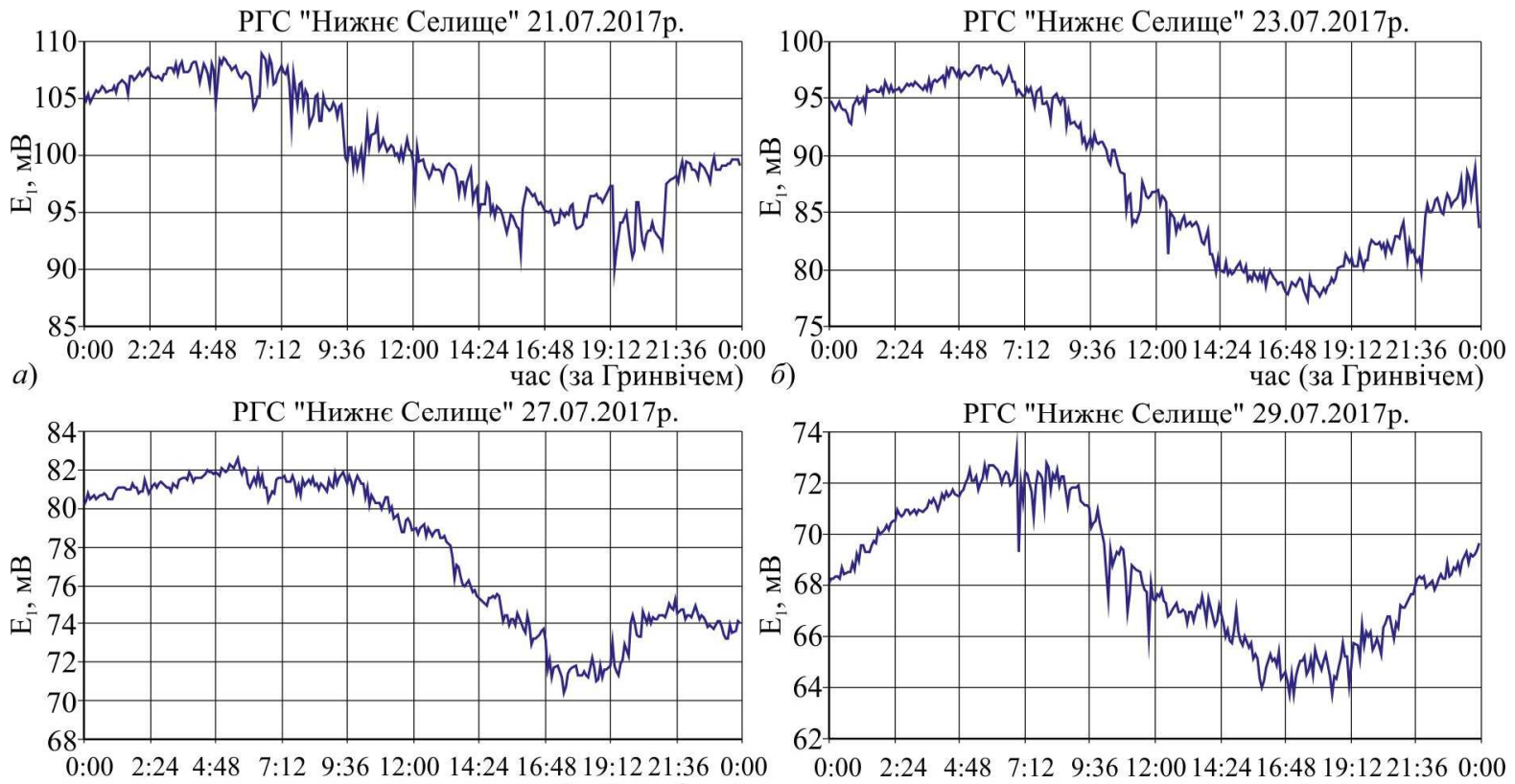

в) час (за Гринвічем) г)

Рис. 3. Подобова динаміка показників природного електричного поля час (за Гринвічем)

Табл. 2. Показники описової статистики

\begin{tabular}{|c|c|c|c|c|c|c|c|}
\hline \multirow{3}{*}{ Дата } & \multirow{3}{*}{ День 3/п } & \multicolumn{6}{|c|}{ Показники описової статистики } \\
\hline & & \multicolumn{3}{|c|}{ Міри центральної тенденції } & \multicolumn{3}{|c|}{ Міри варіації } \\
\hline & & $\begin{array}{c}\text { середнє } \\
\text { арифметичне }\end{array}$ & медіана & мода & $\begin{array}{l}\text { стандартне } \\
\text { відхилення }\end{array}$ & $\begin{array}{c}\text { розмах } \\
\text { (інтервал) }\end{array}$ & $\begin{array}{c}\text { коефіцієнт } \\
\text { варіації }\end{array}$ \\
\hline 01.07 .2017 & 1 & 131,32 & 131,09 & 138,53 & 3,66 & 17,17 & 0,03 \\
\hline 02.07 .2017 & 2 & 128,48 & 128,57 & 128,92 & 2,32 & 9,77 & 0,02 \\
\hline 03.07 .2017 & 3 & 128,75 & 128,94 & 129,00 & 1,34 & 9,27 & 0,01 \\
\hline 04.07 .2017 & 4 & 127,89 & 127,77 & 130,51 & 2,03 & 8,83 & 0,02 \\
\hline 05.07 .2017 & 5 & 129,55 & 129,49 & 130,66 & 1,40 & 9,05 & 0,01 \\
\hline 06.07 .2017 & 6 & 122,58 & 120,61 & 126,56 & 4,16 & 15,38 & 0,03 \\
\hline 07.07 .2017 & 7 & 119,63 & 120,30 & 121,29 & 2,25 & 11,61 & 0,02 \\
\hline 08.07 .2017 & 8 & 120,09 & 120,34 & 120,41 & 2,29 & 17,55 & 0,02 \\
\hline 09.07 .2017 & 9 & 117,87 & 117,40 & 120,03 & 3,27 & 13,37 & 0,03 \\
\hline 10.07.2017 & 10 & 114,49 & 115,33 & 116,09 & 3,15 & 15,22 & 0,03 \\
\hline 11.07 .2017 & 11 & 109,67 & 108,68 & 108,45 & 4,61 & 20,57 & 0,04 \\
\hline 12.07 .2017 & 12 & 112,73 & 113,01 & 113,22 & 1,49 & 9,77 & 0,01 \\
\hline 13.07 .2017 & 13 & 112,30 & 112,39 & 112,17 & 1,83 & 14,58 & 0,02 \\
\hline 14.07 .2017 & 14 & 110,09 & 109,82 & 114,06 & 3,09 & 12,31 & 0,03 \\
\hline 15.07 .2017 & 15 & 110,46 & 110,78 & 111,42 & 1,54 & 8,27 & 0,01 \\
\hline 16.07 .2017 & 16 & 108,40 & 108,93 & 111,60 & 2,59 & 12,09 & 0,02 \\
\hline 17.07 .2017 & 17 & 107,73 & 108,11 & 111,15 & 2,94 & 15,55 & 0,03 \\
\hline 18.07 .2017 & 18 & 107,96 & 108,66 & 110,23 & 2,78 & 22,89 & 0,03 \\
\hline 19.07 .2017 & 19 & 108,28 & 108,03 & 112,96 & 3,57 & 16,18 & 0,03 \\
\hline 20.07.2017 & 20 & 103,57 & 102,37 & 111,53 & 5,56 & 25,62 & 0,05 \\
\hline 21.07 .2017 & 21 & 100,76 & 99,62 & 98,66 & 5,11 & 18,96 & 0,05 \\
\hline 22.07 .2017 & 22 & 94,04 & 92,56 & 99,76 & 6,03 & 27,07 & 0,06 \\
\hline 23.07 .2017 & 23 & 88,01 & 86,45 & 96,95 & 6,91 & 20,58 & 0,08 \\
\hline 24.07 .2017 & 24 & 79,41 & 77,05 & 87,89 & 7,48 & 45,59 & 0,09 \\
\hline 25.07.2017 & 25 & 75,01 & 75,63 & 69,92 & 3,40 & 11,28 & 0,05 \\
\hline 26.07 .2017 & 26 & 75,87 & 76,11 & 76,35 & 2,46 & 10,81 & 0,03 \\
\hline 27.07 .2017 & 27 & 77,70 & 79,02 & 81,06 & 3,78 & 12,16 & 0,05 \\
\hline 28.07 .2017 & 28 & 70,54 & 71,87 & 75,16 & 4,31 & 13,35 & 0,06 \\
\hline 29.07 .2017 & 29 & 68,53 & 68,40 & 68,24 & 2,59 & 9,54 & 0,04 \\
\hline 30.07 .2017 & 30 & 65,88 & 66,38 & 71,88 & 5,92 & 18,26 & 0,09 \\
\hline 31.07 .2017 & 31 & 65,26 & 65,56 & 65,79 & 4,78 & 16,93 & 0,07 \\
\hline
\end{tabular}

У наступних двох інтервалах ці значення монотонно зменшуються, а в останньому - вони знову зростають 3 тією самою монотонністю. У дослідженні, проведеного методами описової статистики, отримано показники описової статистики, включаючи і коефіцієнт варіації для липня 2017 р., які наведено в табл. 2.

Отримані результати характеризують центральну тенденцію та варіацію даних протягом одного місяця. Значення інших показників описової статистики, таких як: стандартну помилку, асиметрію, ексцес, мінімум, максимум, суму та кількість, у цьому дослідженні не використовували. Справа в тому, що стандартна помилка тут визначається відношенням $\frac{\sigma}{\sqrt{n}}$, де $\sigma, n$-середньоквадратичне відхилення та кількість даних відповідно. Оскільки для усіх подобових даних кількість однакова, то в цьому випадку цілком достатньо як показник варіації середнє квадратичне відхилення.

Показники асиметрії та ексцесу пов'язані з функцією закону розподілу. Оскільки в цьому дослідженні не сто- 
яла задача визначити закон розподілу цих даних, а тому і не було підстав уточнювати ці показники. Щодо показників максимуму і мінімуму, то вони на сучасному етапі досліджень вказують на присутність екстремальних значень. Показник суми - суми значень варіант за однакової кількості варіант для кожної доби можна потрактувати як добову потужність сигналу. Показник кількості даних відомий і однаковий для кожної доби.

На рис. 4 зображено подобові графіки. На графіках дуже чітко виражена істотно нелінійна зміна показників центральної тенденції. Для неї властивою $є$ точка перегину, що означає присутність моди, що й підтверджують дані описової статистики. Важливим візуальним моментом $\epsilon$ те, що характер зміни варіант дуже подібний.

За результатами подобових показників описової статистики побудовано багатовимірне графічне їх подання. Враховуючи істотну відмінність значень показників середнього, моди, медіани від показників середньоквадратичного відхилення, розмаху та коефіцієнта варіації, усі значення були приведені до одиничного інтервалу у своїх вибірках за формулою $\tilde{x}=\frac{x_{i}-x_{\min }}{x_{\max }-x_{\min }}$, де $\tilde{x} \in[0,1]-$ приведене до одиничного інтервалу значення $x_{i}$. Результати такого нормування подано у вигляді багатовимірного графіка на рис. 4.

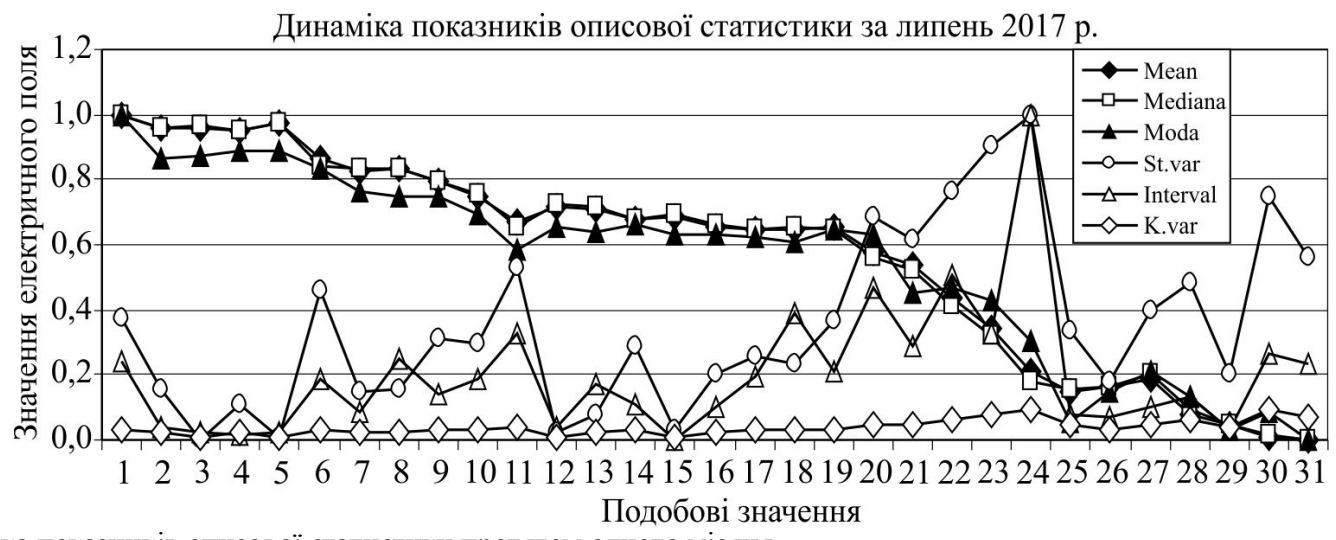

Рис. 4. Динаміка показників описової статистики протягом одного місяця

Подання результатів описової статистики в такий спосіб, як це зроблено на рис. 4, не є традиційним, проте його використання виявило певні збіги показників описової статистики для деяких діб. Наприклад, для показників центральної тенденції особливими можна вважати доби: $1,6,14,19,29$, хоча більш точно їх можна визначити за табл. 2. Для показників варіації такими є 3, 5, 12, 15, 29 доби. Поведінку рівнів (абсолютних значень вимірів електричного поля) протягом місяця можна вважати "квазісинхронною", оскільки форма тренду для кожної доби фактично повторюється, проте винятком може бути лише одна-три доби.

Існування таких збігів може бути випадковою подією або ж результатом відсутності будь-яких впливів, тобто можна вважати стан середовища нормальним, а всі інші - як результат впливу різних чинників. Варіантів їх трактування може бути дуже багато, а тому дослідження у цьому напрямі мають певний науковий сенс для отримання наукового результату.
Наявність таких особливостей у даних потребує нових досліджень цієї місцевості та врахування чинників, які можуть впливати на значення природного електричного поля, наприклад: атмосферні, кліматичні, гравітаційні, сейсмічні, магнітні тощо.

Аналіз трендів подобових часових рядів. Отримані дані можуть бути представлені у вигляді графіка еквідистантного часового ряду, зображеного на рис. 5. Графічне зображення дає загальний вигляд його структури, вказує на характер і вид стаціонарності та коливальну складову. Цей ряд можна формально подати як множину $Y(t)=\left\{y_{j}: y_{j}=y\left(t_{j}\right), j=\overline{1,288}, t_{j}=5 \min , t_{j} \in T\right\}$, впорядкованих у часі випадкових величин і характеризувати (визначити, описати) його як лінійно нестаціонарний, 3 добовою періодичністю, тривалістю $\Delta t=288 \cdot 5 \min =24$ hour , де $T-$ множина 5-хвилинних інтервалів часу. На рис. 5 наведено графіки для діб липня 2017 p.

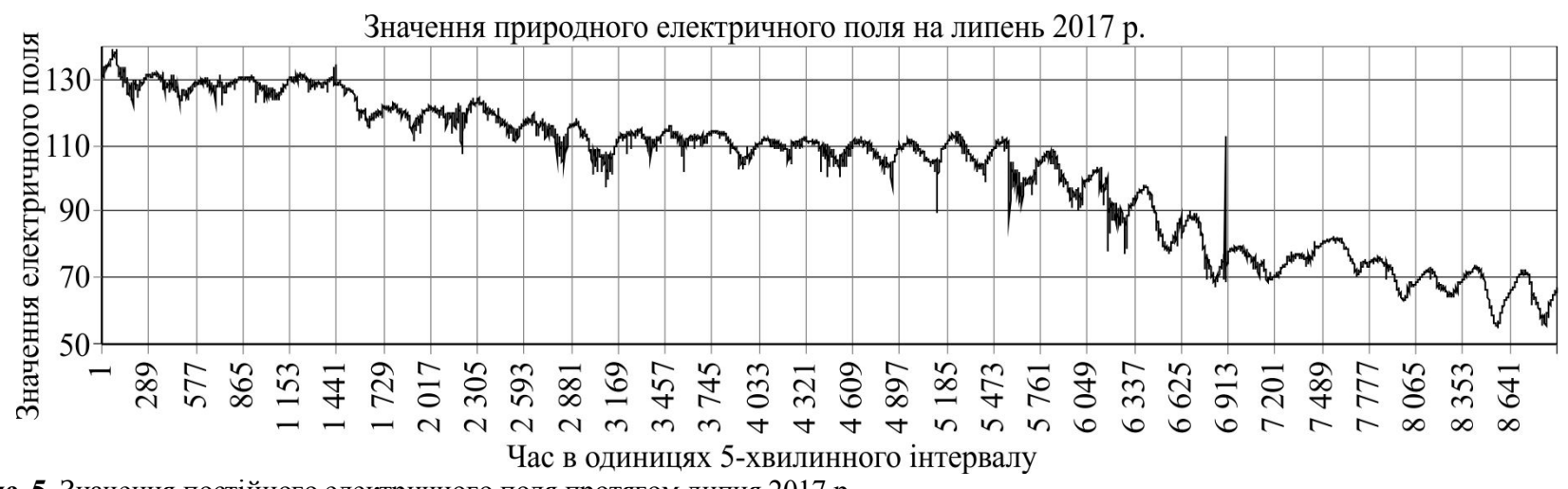

Рис. 5. Значення постійного електричного поля протягом липня 2017 p.

Оскільки форма рівнів часового ряду повторюється, відмінності ії поведінки можна оцінити, використовуючи значення коефіцієнтів моделі, якою апроксимують добові рівні. У цьому випадку, візуально, тренд добових значень має точку перегину, яка переважно припадає на середину доби, як відображено на рис. 6 
01.07 .2017

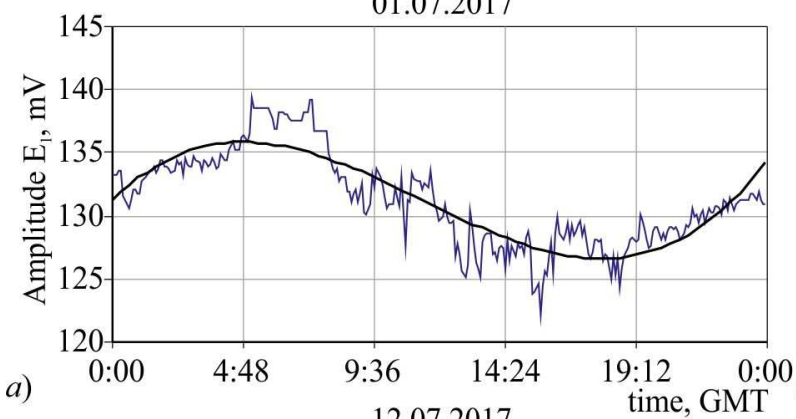

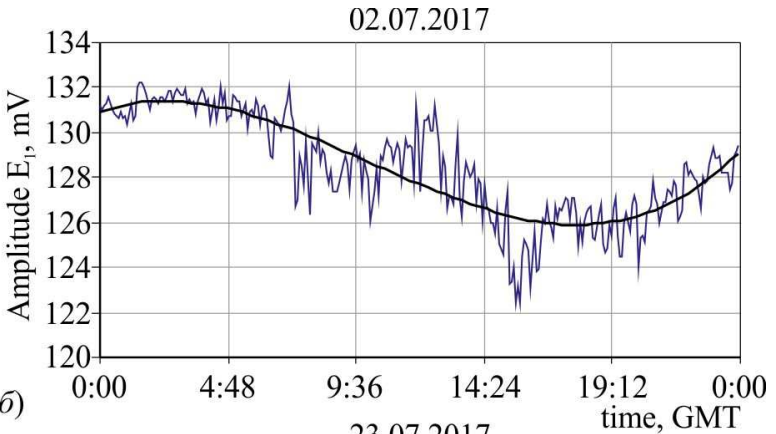

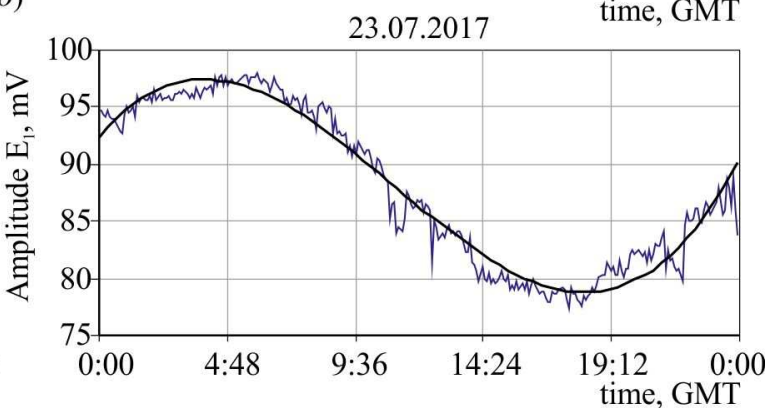

6)

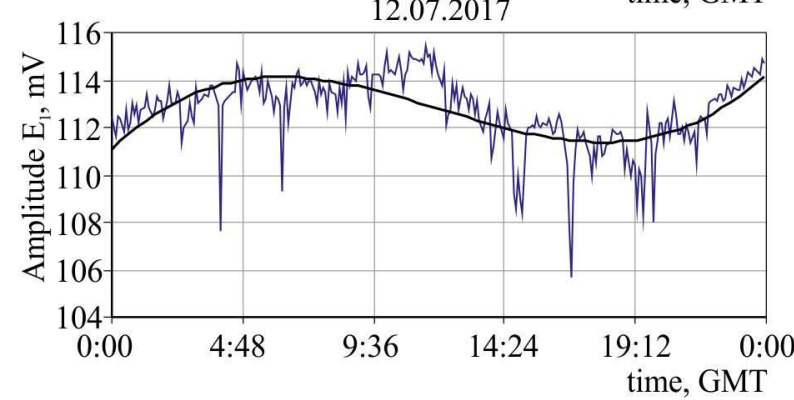

2)

Рис. 6. Тренди подобових даних, апроксимовані поліномами третього степеня

На перший погляд, такою апроксимуючою функцією, як модель тренду $y(t)$, доцільно випробувати поліном третього степеня, а саме:

$$
y(t)=a_{3} \cdot t^{3}+a_{2} \cdot t^{2}+a_{1} \cdot t+a_{0} .
$$

Саме властивість поліному третього степеня, а саме відтворювати залежність, яка має точку перегину, робить його найпростішою функцією для апроксимації цих даних. Основним недоліком поліномів $є$ те, що практично неможливо надати їх коефіцієнтам смислового навантаження чи фізичного тлумачення. Однак, зроблено спробу такої апроксимації. На рис. 6 наведено графіки апроксимованих трендів подобових даних.

У табл. 3 подано значення коефіцієнтів апроксимуючих поліномів.

Як і у випадку з показниками описової статистики використано підхід - подання значень коефіцієнтів поліному на одному графіку, зображеному на рис. 7. Особливість результатів полягає в тому, що тут також існують специфічні точки, в яких абсолютні значення коефіцієнтів $a_{j}$, де $j=0,1,2,3$, мають дуже близькі значення.

Табл. 3. Результати апроксимації даних для кожної доби

\begin{tabular}{|c|c|c|c|c|c|c|c|}
\hline \multirow{2}{*}{ Доби з/п } & \multicolumn{4}{|c|}{ Коефіцієнти поліному } & \multirow{2}{*}{ R2 } & \multirow{2}{*}{ Середнє Y } & \multirow{2}{*}{ model } \\
\hline & a3 & $\mathrm{a} 2$ & a1 & $\mathrm{a} 0$ & & & \\
\hline 1 & 112,83 & $-160,06$ & 50,399 & 131,27 & 0,7843 & 131,32 & 131,3193 \\
\hline 2 & 41,283 & $-52,377$ & 9,3432 & 130,94 & 0,7488 & 128,48 & 128,4771 \\
\hline 3 & 15,403 & $-13,579$ & 0,0221 & 129,42 & 0,3302 & 128,75 & 128,7533 \\
\hline 4 & 40,329 & $-44,379$ & 4,3725 & 130,41 & 0,7747 & 127,89 & 127,8859 \\
\hline 5 & 30,727 & $-38,171$ & 9,4932 & 129,84 & 0,3885 & 129,55 & 129,5422 \\
\hline 6 & 62,384 & $-76,276$ & 7,748 & 128,52 & 0,9198 & 122,58 & 122,5756 \\
\hline 7 & 63,741 & $-79,745$ & 18,979 & 120,79 & 0,7487 & 119,63 & 119,6289 \\
\hline 8 & 17,52 & $-7,2516$ & $-7,1141$ & 121,69 & 0,4313 & 120,09 & 120,0914 \\
\hline 9 & 33,85 & $-39,632$ & $-0,8752$ & 123,05 & 0,8976 & 117,87 & 117,8758 \\
\hline 10 & 64,724 & $-91,144$ & 25,436 & 115,97 & 0,6381 & 114,49 & 114,4897 \\
\hline 11 & 70,745 & $-75,838$ & 0,4634 & 117,02 & 0,8674 & 109,67 & 109,6669 \\
\hline 12 & 46,178 & $-69,773$ & 26,774 & 111,06 & 0,4236 & 112,73 & 112,7288 \\
\hline 13 & $-11,221$ & 31,493 & $-22,318$ & 115,77 & 0,3997 & 112,30 & 112,3073 \\
\hline 14 & 64,952 & $-79,563$ & 13,084 & 113,83 & 0,9097 & 110,09 & 110,092 \\
\hline 15 & 34,995 & $-40,494$ & 8,162 & 111,13 & 0,5412 & 110,46 & 110,4578 \\
\hline 16 & 45,503 & $-49,228$ & 3,8593 & 111,5 & 0,6568 & 108,40 & 108,3963 \\
\hline 17 & 78,904 & $-105,7$ & 27,344 & 109,57 & 0,8803 & 107,73 & 107,734 \\
\hline 18 & 90,163 & $-123,84$ & 37,578 & 107,92 & 0,7505 & 107,96 & 107,9636 \\
\hline 19 & 96,442 & $-130,49$ & 34,345 & 110,49 & 0,9241 & 108,28 & 108,2761 \\
\hline 20 & 94,054 & $-102,42$ & 6,0453 & 111,17 & 0,7468 & 103,57 & 103,5705 \\
\hline 21 & 114,98 & $-158,75$ & 40,429 & 104,72 & 0,9284 & 100,76 & 100,7684 \\
\hline 22 & 124,53 & $-163,79$ & 35,526 & 99,73 & 0,8388 & 94,04 & 94,03498 \\
\hline 23 & $\begin{array}{l}178,32 \\
\end{array}$ & $-246,57$ & 66,487 & 92,37 & 0,9637 & 88,01 & 88,00613 \\
\hline 24 & 185,08 & $-267,01$ & 80,343 & 81,971 & 0,8334 & 79,41 & 79,41108 \\
\hline 25 & 32,683 & $-55,533$ & 15,123 & 77,775 & 0,924 & 75,01 & 75,00806 \\
\hline 26 & 46,827 & $\begin{array}{l}-74,739 \\
\end{array}$ & 39,861 & 69,163 & 0,8854 & 75,87 & 75,86668 \\
\hline 27 & 78,867 & $-122,61$ & 40,22 & 78,737 & 0,9224 & 77,70 & 77,69869 \\
\hline 28 & 100,35 & $-144,68$ & 41,727 & 72,815 & 0,9246 & 70,54 & 70,5427 \\
\hline 29 & 96,522 & -141 & 48,317 & 67,248 & 0,9305 & 68,53 & 68,52966 \\
\hline 30 & 180,7 & $-259,85$ & 81,759 & 66,446 & 0,925 & 65,88 & 65,87847 \\
\hline 31 & 178,78 & $-261,8$ & 90,269 & 62,712 & 0,9228 & 65,26 & 65,26173 \\
\hline
\end{tabular}




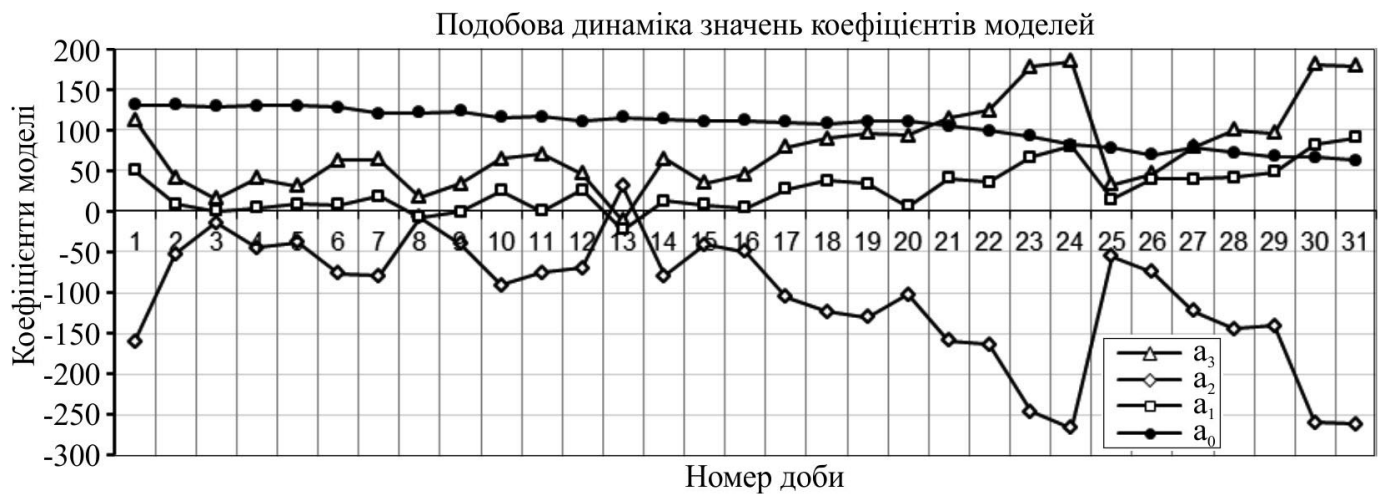

Рис. 7. Зміна коефіцієнтів моделі щодоби

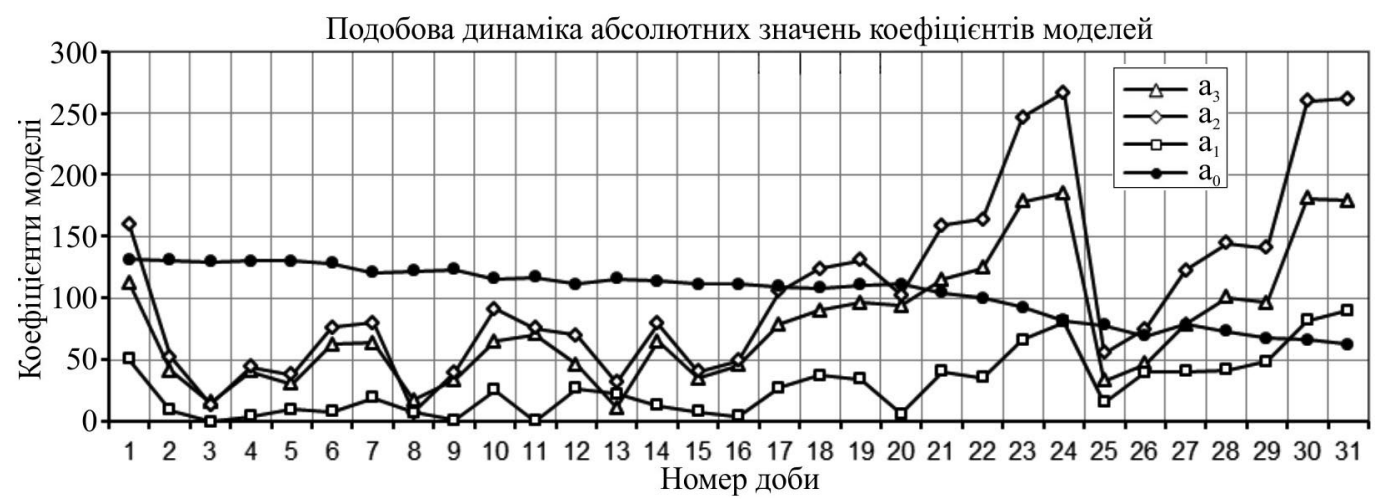

Рис. 8. Динаміка абсолютних значень коефіцієнтів моделей

Оскільки другий коефіцієнт $a_{2} \epsilon$ від'ємним, внаслідок цього спостерігаємо симетричність графіків для коефіцієнтів $a_{2}$ і $a_{3}$. Якщо подати цей графік не реальними значеннями, а абсолютними, тобто представити значення коефіцієнтів $a_{j}$ як абсолютні значення $\left|a_{j}\right|$, то графік матиме вигляд зображений на рис. 8.

Уже візуальний аналіз графіків на рис. 8 вказує на особливі точки, в яких значення коефіцієнтів моделі збігаються. Такі збіги є нерегулярними і не абсолютними, тобто повний збіг не завжди відбувається. Для таких діб, як 3, 8, 13 і 25, збіги є досить близькими. Природу цих збігів важко пояснити, використовуючи лише ці дані. Очевидно, що такі збіги передусім можна вважати випадковими (як збіг випадкових обставин).

Коефіцієнт $a_{0} \epsilon$ дуже близьким до середнього арифметичного для цієї доби. Його поведінка, як видно 3 графіка на рис. 7, є досить монотонною і відносно гладкою. Порівнюючи 3 іншими місяцями, простежуємо певну коливальність цього показника 3 періодом в декілька місяців. Цей феномен також потребує відповідних досліджень.

Подання поведінки коефіцієнтів $a_{i}$ моделі на одному графіку вказує на те, що $a_{2}$ i $a_{3}$ змінюються пропорційно, і на деяких етапах їх повторює показник $a_{1}$. Отже, для деяких діб існує подібність у структурах апроксимуючих моделей. Оскільки якість апроксимації за коефіцієнтом детермінації $R^{2}>0,89$, можна вважати, що відповідність моделі добовим значенням $\epsilon$ достатньою для використання цього підходу - встановлення специфічних точок динаміки природного електричного поля для цієї локальної режимної геофізичної автоматичної станції "Нижнє Селище".

Висновки. Попереднє оброблення первинних геофізичних даних, автоматично переданих із режимної геофізичної станції щодобовими специфічними файлами, підтвердило доцільність використання таких підходів:
1. Використання мір центральної тенденції та мір варіації дають не лише основні загальні характеристики отриманої вибірки даних, але і їх подання у вигляді багатоелементного графіка, що дає змогу виявити окремі специфічні точки для послідовності діб місяця. Їхня специфічність полягає в тому, що вони вказують на доби, які за цими показниками $є$ найбільш подібні між собою. Цей феномен можна трактувати по-різному: відсутність зовнішніх впливів, у ці доби відбувся один і той самий вплив тощо. Цілком зрозуміло, що на всьому проміжку, отриманих за весь час роботи станції даних, цей феномен мусить мати якесь пояснення в майбутніх дослідженнях.

2. Побудова подобового часового ряду з отриманих даних показала, що дані в інтервалі доби мають дуже часто повторюваний за формою тренд. Для аналізу цього явища подобові рівні часового ряду були апроксимовані поліномом третього степеня. Багатовимірний часовий ряд, утворений з коефіцієнтів цього поліному-моделі також показав збіги їх значень для деяких діб. Ці збіги хоча і не відповідають таким для описової статистики, проте нехтувати ними, не знаючи причин, вважаємо не варто, оскільки вони несуть якусь інформацію, можливо і дуже важливу.

Отже, можна стверджувати, що використання методів описової статистики та часових рядів є доцільним для оброблення первинних даних, оскільки їх результати визначають нові задачі для подальшого аналізу не тільки геофізичних даних, але й інших подібних явищ, таких як: кардіологічні сигнали, показники сонячної активності та інші.

\section{Перелік використаних джерел}

Cletus C. Blum, Timothy C. White, Edward A. Sauter, Duff C. Stewart, Paul A. Bedrosian, and Jeffrey J. (2017). Love: Geoelectric monitoring at the Boulder magnetic observatory, Geosci. Instrum. Method. Data Syst., 6, 447-452, https://doi.org/10.5194/gi-6-447-2017 
David Fuertes, Carlos Toledano, Ramiro Gonzalez, Alberto Berjon, Benjamin Torres, Victoria E. Cachorro, \& Angel, M. (2018). de Frutos: CAELIS: software for assimilation, management and processing data of an atmospheric measurement network, Geosci. Instrum. Method. Data Syst., 7, 67-81. https://doi.org/10.5194/gi-7-67-2018

EMSC. (2018). Yevropeisko-Seredzemnomorskyi seismolohichnyi Tsentr European-Mediterranean Seismological Centre (EMSC): [Website]. Retrieved from: https://www.emsc-csem.org (Date of treatment 18.07.2018). Title from the screen. [In Ukrainian].

Haniiev, O. Z. (2008). Avtomatyzovana systema zbyrannia i zberihannia seismolohichnykh danykh. Abstract of Doctoral Dissertation for Candidate of Physics and Mathematics Sciences (04.00.22 Geophysics); NAN Ukrainy. Instytut heofizyky im. S. I. Subbotina. Kyiv. 17 p. [In Ukrainian].

Haniiev, O. Z., Petrenko, K. V., Sheremet, Ye. Ye., Vakulovych, D. V., \& Krasnyi, V. A. (2011). Orhanizatsiia seismolohichnoho punktu sposterezhen na ostrovi Zmiinyi. Heofizychnyi zhurnal, 33(2), 122-128. [In Ukrainian].

INTERMAGNET. (2018a). International Real-time Magnetic Observatory Network: [Website]. Retrieved from: http://www.intermagnet.org http://www.intermagnet.org/index-eng.php (Date of treatment 17.07.2018). Title from the screen.

INTERMAGNET. (2018b). International Real-time Magnetic Observatory Network: [Website]. Retrieved from: http://www.intermagnet.org/activitymap/activitymap-eng.php $\quad$ http://www.intermagnet.org/data-donnee/dataplot-eng.php? type $=\mathrm{xyz}$ (Date of treatment 17.07.2018). Title from the screen.

IRIS. (2018a). Incorporated Research Institutions for Seismology (IRIS): [Website]. Retrieved from: http://www.iris.edu/hq/ http://ds.iris.edu/seismon/ http://www.iris.edu/hq/programs/gsn (Date of treatment 17.07.2018). Title from the screen.

IRIS. (2018b). Incorporated Research Institutions for Seismology (IRIS): [Website]. Retrieved from: http://www.usarray.org/researchers/obs/magnetotelluric http://ds.iris.edu/gmap/ US-MT (Date of treatment 17.07.2018). Title from the screen.
ISC. (2018). Mizhnarodnyi seismolohichnyi tsentr International Seismological Centre (ISC): [Website]. Retrieved from: http://www.isc.ac.uk/index.php (Date of treatment 18.07.2018). Title from the screen. [In Ukrainian].

Mazurkin, P. M. (2016). Posutochnaia dinamika ob'ema i tceny nefti brent i vliianie na finansovyi potentcial trekh faktorov. Krymskii nauchnyi vestnik, 2(8), 205-224. [In Russian].

NGDC. (2018a). The National Geophysical Data Center (NGDC) and its sister data centers merged into the National Centers for Environmental Information (NCEI): [Website]. Retrieved from: http://www.ngdc.noaa.gov http://www.ngdc.noaa.gov/ngdcinfo/aboutngdc.html (Date of treatment 17.07.2018). Title from the screen.

NGDC. (2018b). The National Geophysical Data Center (NGDC) and its sister data centers merged into the National Centers for Environmental Information (NCEI): [Website]. Retrieved from: $\mathrm{ftp}: / / \mathrm{ftp}$.ngdc.noaa.gov/wdc/geomagnetism/data/observatories/definitive ftp://ftp.ngdc.noaa.gov/STP/GEOMAGNETIC DATA (Date of treatment 17.07.2018). Title from the screen.

Pidvirnyi, O. I. (2013). Do pytannia zbyrannia i peredachi pervynnykh heofizychnykh danykh v avtomatyzovanykh systemakh. Heodynamika, 2(15), 286-288. [In Ukrainian].

USGS. (2018). USGS Geomagnetism Program: [Website]. Retrieved from: http://geomag.usgs.gov/ http://geomag.usgs.gov/plots/ (Date of treatment 17.07.2018). Title from the screen.

Verbytskyi, S. T., \& Verbytskyi, Yu. T. (2011). Suchasnyi stan ta perspektyvy rozvytku seismolohichnykh doslidzhen v Karpatskomu rehioni Ukrainy. Heodynamika, 2(11), 35-37. [In Ukrainian].

Verbytskyi, S. T., Stetskiv, O. T., Verbytskyi, Yu. T., Rozhok, N. I., Stasiuk, A. F., \& Pronyshyn, R. S. (2009). Systema zbyrannia, obroblennia ta analizu seismolohichnykh danykh Karpatskoho rehionu. Heofizychnyi zhurnal, 31(1), 125-131. [In Ukrainian].

Verbytskyi, Yu. T. (2013). Metodychni ta prykladni aspekty kompleksnoho banku heofizychnoi informatsii Karpatskoho rehionu. Abstract of Doctoral Dissertation for Candidate of Physics and Mathematics Sciences (04.00.22 - Geophysics); NAN Ukrainy, Instytut heofizyky im. S. I. Subbotina. Kyiv. 20 p. [In Ukrainian].

\title{
Р. М. Каминский ${ }^{1}$, Н. Б. Шаховская ${ }^{1}$, Л. Г. Савкив ${ }^{2}$, Я. Ю. Варецкий', С. В. Саварин ${ }^{1}$
}

${ }^{1}$ Национальный университет "Львовская политехника", г. Львов, Украина

${ }^{2}$ Карпатское отделение Института геофизики им. С. И. Субботина, НАН Украинь, г. Львов, Украина

\section{МЕТОДЫ ПРЕДВАРИТЕЛЬНОЙ ОБРАБОТКИ ПЕРВИЧНЫХ ГЕОЭЛЕКТРОМАГНИТНЫХ ДАННЫХ, ПОЛУЧЕННЫХ ИЗ РЕЖИМНОЙ ГЕОФИЗИЧЕСКОЙ АВТОМАТИЧЕСКОЙ СТАНЦИИ}

\begin{abstract}
Представлены результаты предварительной обработки первичных данных, полученных из режимной геофизической автоматической станции. В качестве методов обработки использованы описательная статистика и моделирование временных рядов. Представление результатов многомерными графиками позволило выявить феномен совпадения в первом показателе описательной статистики, а во втором - совпадение коэффициентов модели для посуточных измерений природного электрического поля. Использование мер центральной тенденции и мер вариации дают не только основные общие характеристики полученной выборки данных, но и их представление в виде многоэлементного графика, что дает возможность выявить отдельные специфические точки для последовательности суток месяца. Их специфичность заключается в том, что они указывают на сутки, которые по этим показателям являются наиболее сходны между собой. Этот феномен можно трактовать по-разному: отсутствие внешних воздействий, в эти сутки произошло одно и то же влияние и так далее. Вполне понятно, что на всем промежутке, полученных за все время работы станции данных, этот феномен должен иметь какое-то объяснение в будущих исследованиях. Таким образом, можно утверждать, что использование методов описательной статистики и временных рядов целесообразно для обработки первичных данных, поскольку их результаты определяют новые задачи для дальнейшего анализа не только геофизических данных, но и других подобных явлений, таких как кардиологические сигналы, показатели солнечной активности и другие.
\end{abstract}

Ключевые слова: исследование постоянного природного электрического поля; предварительная обработка первичных геоэлектромагнитных данных; метод естественного электрического поля.

R. M. Kaminsky', N. B. Shakhovska1, L. G. Savkiv' ${ }^{2}$,Ya.Yu. Varetsky1, S. V. Savaryn ${ }^{1}$ ${ }^{1}$ Lviv Polytechnic National University, Lviv, Lviv, Ukraine ${ }^{2}$ Carpathian branch of the Institute of Geophysics named after S. I. Subbotin, NAS of Ukraine, Lviv, Ukraine

\section{THE METHOD OF PREVIEW PROCESSING OF THE PRIMARY GEOELECTROMAGNETIC DATA RECEIVED FROM A MODIFIED GEOPHYSICAL AUTOMATIC STATION}

Preliminary processing of primary geophysical data, automatically transmitted from the regime geophysical station to the daily specific files confirmed the feasibility of using such approaches. The purpose of the research is to focus on the choice of simple methods of primary data processing and the development of appropriate mathematical models of the dynamics. The results of prelimi- 
nary processing of the primary data obtained from the regime geophysical automatic station are submitted. Descriptive statistics and simulation of time series were used as processing methods. The presentation of the results by multidimensional graphs allowed revealing the phenomenon of coincidence in the first indicators of descriptive statistics, and in the second, the coincidence of the model's coefficients for the daily measurements of the natural electric field. Using the measures of the central trend and the degree of variation gives both the basic general characteristics of the received sample of data, and their representation in the form of a multi-element graph allows you to identify specific specific points for the sequence of days of the month. Their specificity lies in the fact that they point to the days that are the most similar among these indicators. This phenomenon can be interpreted as follows: the absence of external influences, in those days there was one and the same influence and the like. This phenomenon is obvious to have some explanation in future studies over the entire gap obtained during the entire work time of the data station. Construction of the daily time series from the data obtained showed that the data in the interval of time have very often repetitive form of the trend. For the analysis of this phenomenon, the levels of the time series were approximated by the polynomial of the third degree. A multidimensional time series, formed from the coefficients of this polynomial model, also showed the coincidence of their values for several days. These coincidences though do not correspond to such descriptive statistics, but neglect them without knowing the reasons we do not think, because they carry some information, maybe very important. Thus, it can be argued that the use of descriptive statistics and time series methods is appropriate for the processing of primary data, since their results define new tasks for further analysis of not only geophysical data but also other similar phenomena such as cardiac signals, solar activity and others

Keywords: research of constant natural electric field; preliminary processing of primary geoelectromagnetic data; the method of natural electric field. 